It is not yet known whether the morphological anomalies observed are to be considered as simple variations, as the ephemeral manifestations of hormonal or pharmaco-dynamical actions, as 'Dauer'. modifications, or as true mutations. The manner of the 'mendelization' of their offsprings will answer these questions next season.

These investigations were partly aided by grants of the Hungarian Department of Agriculture, Bureau of Researches.

${ }^{1}$ Havas, L. J., Bull. Assoc. Franc. Cancer, 26 (6), 1 (1937).

\& Havas, L. J., Growth, 2, 257 (1938).

${ }^{3}$ Havas, L. J., Soc. Roy. Sci. Med. et Nat., Bruxelles, Conf. 8 Janv., 1940 .

- Müntzing, A., and Runquist, E., Hereditas, 25 (4), 491 (1939).

${ }^{6}$ Levan, A., Hereditas, 28, 244 (1942).

- Newcomer, E. H., Science, 101, 677 (1945)

"Hirobe, T., Jap. J. Genet, 15, 64 (1939).

"Cited by Rostand, J., "Science et Génération" (Fasquelle, Paris, $1940), 118$.

- Havas, L. J., Bull. Acad. Roy. Belge, Cl. Sci., (v), 318 (1942).

${ }^{10}$ Kostoff, D., Nature, 142, 753 (1938).

${ }^{11}$ King, L. S., and Sullivan, M., Arch. Pathol., 43, 374 (1947).

${ }^{18}$ Sullivan, M., and Wechsler, H. J., Science, 105, 42 (1947).

${ }^{13}$ Wigglesworth, V. B., Quart. J. Micro. Sci., 79, 91 (1936).

" Bounhiol, J. J., Arch. Zool. Not. et Rev., 81, 54 (1939).

\section{INDUSTRIAL CO-OPERATION}

$\mathrm{T}$

$\mathrm{HE}$ delegates to the annual conference of the British Association for Commercial and Industrial Education, which was held at Ashridge in October 1947, were welcomed by the president of the Association, Sir Charles Tennyson, who stated that "the task confronting us to-day will require a range of knowledge in natural science, economics, sociology and psychology of which our grandfathers can never have dreamed, and a degree of perseverance, common sense and mutual consideration which must be a severe tax on human frailty. It is clear that education can make an inestimable contribution to the solution of these difficulties but ... there seems to be a general consensus of opinion that education has made the mistake of confining itself to 'subjects', dealing with these in isolation and not relating them sufficiently to the needs and eircumstances of society and man's everyday life and avocations.

"On the other hand, industry and commerce... have failed to realize that they have a responsibility to promote the development of individual capacity and sense of citizenship. They have also failed to realize how much academic training can do to improve the efficiency of the young employee who has been regarded simply as an economic unit to be made as immediately productive as possible at the smallest expense. That is not the way to produce skilled workmen, efficient managers, broadminded and creative technicians or good citizens."* Sir Charles then declared that the motive in calling the delegates together was the belief that unless educationists, industrialists and representatives of the workers come together to deal with this question of education and training in the spirit of research and whole-hearted co-operation Britain has little chance of overcoming its difficulties.

The initial address was given by Mr. F. C. Hooper, formerly director of business training to the Ministry of Labour and National Service, who dealt with the part which management should play in bringing

* "The Short Road to Industrial Co-operation." Published by the British Association for Commercial and Industrial Education, 107
Baker Street, London, W.1. 58. about industrial co-operation. When an administration is faced with the need to change a situation, he said, its first essential task is to change the habitpatterns that have been built up under and by the old situation that is to be changed. The immediate situation we wish to change is one of poor or halfhearted co-operation between management and labour in business and to establish in its place a situation of full and enthusiastic co-operation in which management and labour are a real organic working team. This co-operation can only come if both parties recognize that they possess a single overriding common interest which wholly justifies them in establishing a common aim and which inspires them in working together to achieve it. Of the forces which stand in the way of establishing full co-operation one of the most important is the actual nature of the trade unions. Formed as fraternities to curb and combat the power of employers, to-day they have become essentially 'antibodies'. When management considers how it can most effectively attain the co-operation of its employees, it must always reckon with the fact that the rank and file of organised labour are extremely suspicious of management and that this suspicion will not be eradicated in any short term. The only way in which antibodyism and suspicion could be abolished would be by the logic of events from without and the efforts of trade union leadership directed to the same end from within. Mr. Hooper then suggested various means by which the climate of work could be made favourable to produce the maximum response by all workers in industry, and suggested that, in his opinion, schemes of education and training are of paramount importance.

Replying for the trade unions, Mr. Harold Clay, assistant general secretary of the Transport and General Workers Union, stated that over a very wide field in industry, especially among the industrial workers, there was considerable suspicion, doubt and hesitation about schemes for education and training. There undoubtedly existed in the minds of the wide body of the working population the idea that some of the 'enlightened' ventures that are now being embarked upon are merely another form of dope or opiate to keep the workers quiet at this particular time. In his opinion, education and training was part of a much wider problem, and until a real sense of social purpose had been built up which was accepted by all sections in industry, any attempt to find a solution to our present difficulties would fail. This sense of social purpose should be quite distinct from individual advantage, firm advantage or industry advantage. Relationships generally between management and workers, and those they represent, should be such that co-operation must be possible over a very wide field. "There must be opportunities for the discussion of all those issues that affect, or appear to affect the interest of the workers, and this includes quite a number of problems that have hitherto been regarded as the sole concern of management."

Other speakers went on to consider how more effective co-operation could be achieved between the planners of education and the planners in industry and commerce, as well as those aspects of education and training which had proved effective in promoting good relationships between the employee and em. ployer. This was followed by a session in which Mr. Noel Hall, principal of the Administrative Staff College at Henley, discussed the further training of higher management and particularly the way in 
which this training would be given at the Administrative Staff College.

Finally, the industrialist's point of view was put clearly and forcibly by Sir Ronald Weeks, deputy chairman of Vickers, Ltd., who defined the present obligations of both employer and employee. In his view the employer must regard himself as the trustee, be honest and fair in all his dealings, study the psychology of his employees, do everything possible to ensure good working conditions, know his own job and train his staff accordingly, pay an adequate wage for an honest day's work, endeavour to give his employees a sense of security and reasonable incentives for advancement, and finally, he must provoke a sense of loyalty and a 'sense of belonging'. The employee should observe obedience to rules and a sense of discipline, loyalty to the employer, and an honest day's work.

Sir Ronald emphasized Mr. Clay's belief that spontaneous co-operation cannot come without a sense of social purpose, and indicated that to-day the size of the pay packet on one side and the profit motive on the other are considered to be much more important than the conception of the universal and social purpose in industry. Sir Ronald then put forward various suggestions for the future improvement of industrial relations, indicating ways and means in which schemes of education and training for all grades could be introduced and implemented.

Altogether some 170 delegates attended the conference and, although they represented industries and public services having widely different problems and approached the discussion from widely different points of view, the conference was remarkable for the almost complete unanimity about the solutions that should be applied to Britain's economic crisis. Among the delegates were many representatives of firms who have been world pioneers in schemes of employee education and training and who have proved by experience that such schemes are eminently practical and beneficial. At this time of emergency their experience should not be ignored. T. H. HAwkINS

\section{HISTORY OF SCIENCE IN EDUCATION}

\footnotetext{
A JOINT meeting of the British Society for the History of Science with the Science Masters' Association, the Historical Association and the Association of Women Science Teachers was recently held at the Science Museum to discuss the subject "The Place of the History of Science in Education". The meeting was very well attended, and the chair was occupied by Dr. E. J. Holmyard, who took the opportunity of welcoming Prof. George Sarton as an honorary member of the British Society for the History of Science. The opening speakers were Dr. F. Sherwood Taylor, Mr. G. Fowles (a former chairman of the Science Masters' Association), Mr. S. M. Toyne (chairman of the Council of the Historical Association) and Miss L. E. Higson (secretary, Association of Women Science Teachers).

Dr. Sherwood Taylor said that he believed the principal aim of teaching science in the schools was to enable young people to make wise and sound decisions in their daily life. The teaching should also make clear how far, and in what regions, one may trust science. Instruction in the history of science could obviously provide a valuable means to this end.
}

There was too much tendency at the present day to teach factual rudiments only, and he would like to see more insistence upon scientific method. Where this involved a repetition of famous historical experiments, difficulties were bound to arise, since many of them did not lend themselves to the conditions of school curricula. There seemed to be a great opportunity for historical scientific films in this connexion, but such films must be of high accuracy or they would do more harm than good.

Mr. Fowles said that, in teaching science in schools,. the psychological factors were very difficult in that only about 5 per cent of the pupils could ever reach the standard represented by a university scholarship, and that the method of presentation had to be conditioned mainly by the needs of the remaining 95 per cent. So far as the historical method of teaching science was concerned, he thought there were three different aspects which he would describe as anecdotal, recapitulatory and evolutionary. Everybody was agreed that the anecdotal aspect was useful; but he doubted whether it was of value in explaining scientific method. The recapitulatory system was not altogether without defect, since pioneering work did not always provide the most direct or logical solution of the problem involved. General evolutionary consideration of scientific advance had more to recommend it, and this would be particularly valuable in teaching science to classical sixth forms. He agreed that some knowledge of the history of science was of great importance, but felt that it should form part of the general history course rather than of the science course.

Mr. Toyno described the methods he had adopted of teaching the history of science to boys on all sides in a public school. He felt that the history of science should form a part of the history course, but not at the expense of the history normally taught. $\mathrm{He}$ emphasized the fact that social history cannot pro. perly be explained without a knowledge of the history of science.

Miss Higson expressed the view that instruction in the history of science would be of advantage to all pupils in schools, especially those of sixth-form age. She had been distressed to find how little mention of men of science and scientific discovery was made in the standard histories used in the schools, and gave some examples. Apparently the only man of science to attract the attention of historians was Darwin. Miss Higson also remarked that she felt that science and its history should form an integral part of the 'current events' periods in schools, and agreed with Dr. Sherwood Taylor's plea for more science films.

Dr. Sarton said that in his opinion the value of the history of science was threefold. In the first place it was essential for science itself. Secondly, it formed an excellent introduction to philosophy. Thirdly, it had inherent cultural advantages, and these he would rate the highest. He gave an account of his own two-year course on the history of science at Harvard, in which he presented his students with a general survey of the developments of science and scientific thought from the earliest times to the present day, in four sessions of thirty-five lectures each.

The discussion then became general, and the con. sensus of opinion was that a very strong case had been made out for the inclusion of the history of science in the course for both schools and universities, and most speakers agreed that the teaching should form part of general historical study. 